\title{
40. SUBSIDENCE AND DEEPENING OF THE GALICIA MARGIN: THE PALEOENVIRONMENTAL CONTROL ${ }^{1}$
}

\author{
Michel Moullade, Laboratoire de Micropaléontologie et Géologie Marines, Université de Nice, Nice, France \\ Marie-Françoise Brunet, Département de Géologie Dynamique, Université Pierre et Marie Curie, Paris, France \\ and \\ Gilbert Boillot, Laboratoire de Géodynamique Sous-Marine, CEROV, Villefranche-sur-Mer, France
}

\begin{abstract}
The evolution of the syn-rift and post-rift deepening of the Galicia margin is studied by application of the subsidence model of McKenzie (1978), which implies a homogeneous stretching hypothesis. The resulting paleobathymetric curve is further refined by paleoenvironmental depth constraints based on the composition of microfossil assemblages. Results obtained by the two methods are in close agreement and suggest a faster subsidence rate during the first part (Valanginian-Hauterivian) than during the second part of the rifting period. Minor discrepancies that arise in paleodepth estimations are attenuated by considering a subsidence model based on Wernicke's (1985) hypothesis, which also supposes heterogeneous stretching.
\end{abstract}

\section{INTRODUCTION}

Carbonate sediments were deposited 150 m.y. ago, during the Tithonian, in the location of the current Galicia margin, at a water depth of less than $100 \mathrm{~m}$ (Shipboard Scientific Party, 1987b; Moullade, Loreau, et al., this volume). At Ocean Drilling Program (ODP) Site 638, the water depth presently exceeds $4600 \mathrm{~m}$ (Fig. 1). By adding the thickness of the sedimentary cover (about $1200 \mathrm{~m}$ ) to that of the water column, it appears that the basement of the margin has subsided considerably, by almost $6 \mathrm{~km}$ since $150 \mathrm{Ma}$.

There are two different approaches that can be applied to reconstruct the subsidence history of this area:

1. Paleobathymetric interpretations based on micropaleontologic data can be used, with some approximation, to determine the progression of margin deepening with time.

2. It is also possible to construct a theoretical subsidence curve for the Galicia margin by comparison to a subsidence model previously derived from data at other margins and intracontinental sedimentary basins. The resulting theoretical paleobathymetric curve can be compared to the actual paleoenvironmental data.

In this paper, we present both of these approaches so that the resulting subsidence curve will best describe the deepening of the margin from the Tithonian through the present at Sites 638, 639, and 641 (Fig. 1).

\section{THEORETICAL MARGIN SUBSIDENCE AT SITES 638, 639, AND 641}

In this section, curves for both theoretical subsidence and deepening of the seafloor are considered. The "tectonic" subsidence curve is arbitrarily plotted for the theoretical situation of a continental basement devoid of sediments and a constant sea level. The paleobathymetric curve, the only model that can be directly compared to the paleoenvironmental data, is derived from the theoretical tectonic subsidence curve, taking into account sediment loading and worldwide sea-level changes.

${ }^{1}$ Boillot, G., Winterer, E. L., et al., 1988. Proc. ODP, Sci. Results, 103: College Station, TX (Ocean Drilling Program).

\section{The Subsidence Model: Hypotheses and Data}

As a first approach, we used a model that implies a homogeneous lithospheric stretching, as initially proposed by McKenzie (1978) and later refined and modified (see, for instance, Royden, 1982). According to this model, horizontal stretching and thinning affect lithosphere assumed to be initially $125 \mathrm{~km}$ thick and including a crust $30 \mathrm{~km}$ thick; the temperature at the lowermost part of the lithosphere is $1333^{\circ} \mathrm{C}$. The continental crust supposedly produces some amount of heat by radioactivity. We did not take into account thermal disturbance introduced by the relatively thin $(1200-\mathrm{m})$ sedimentary cover nor the cooling effect by lateral conduction, the result of which is to somewhat accelerate the heat loss and, accordingly, the deepening and subsidence (Watremez, 1980; Alvarez, 1984). For our calculations, we assumed that the water depth and sediment thickness at Site 638 are representative of the studied area. This constitutes an approximation because the sediment thickness decreases on top of tilted blocks (close to the drilling sites) and increases in the halfgraben immediately to the east of the drilling sites.

We determined parameters and defined simplifying hypotheses for this model as follows:

1. Time scale is adopted from Kent and Gradstein (1985).

2. The present water depth and syn- and post-rift sediment thicknesses at Sites 638 and 639 allow us. to estimate a value of 3.4 for the coefficient of total thinning $(\beta)$ of the continental lithosphere at this part of the margin. This implies a final crustal thickness of about $10 \mathrm{~km}$, including sediments, assuming an initial crustal thickness of $30 \mathrm{~km}$.

3. The deposition of several hundred meters of carbonates during the Tithonian must have involved a certain amount of subsidence that we attribute to a first episode of extension, dated from $150 \mathrm{Ma}$. However, the amount of lithospheric thinning needed to produce such subsidence is very small $(\beta=$ 1.05).

4. Most of the crustal thinning occurred in the Early Cretaceous, from the Berriasian (140 Ma) to the late Aptian (115 Ma) (i.e., 25 m.y.; Shipboard Scientific Party, 1987a). Two "scenarios" of crustal thinning are possible:

a. by continuous distension, homogeneously distributed during the entire $25-\mathrm{m}$.y. period (total $\beta$ for the Early Cretaceous $=3.21$ ); because of the calculation methods, we must di- 
A

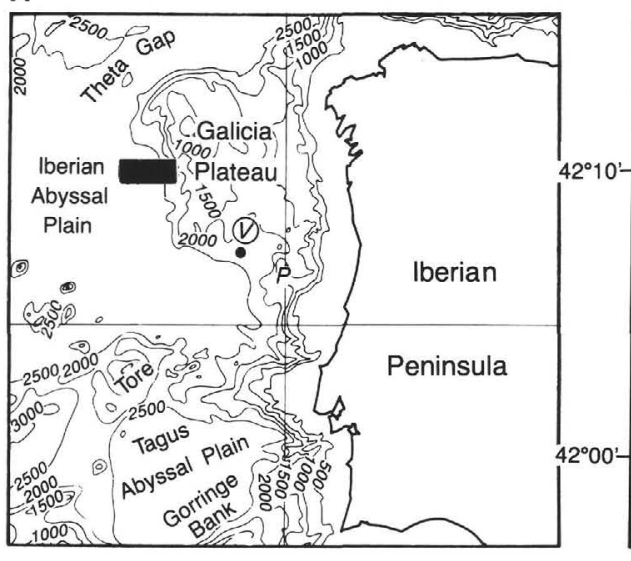

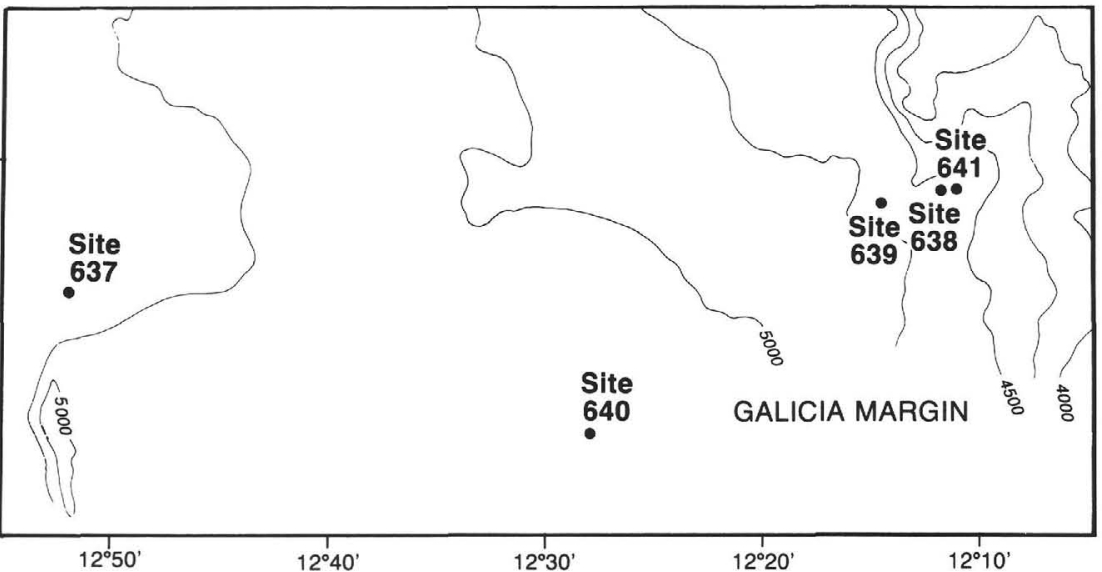

Figure 1. Location of ODP Leg 103 drilling sites along the Galicia margin. A. Box shows location of region in Figure 1B. V = Vigo Seamount; - = Site 398 .

vide the total thinning into instantaneous episodes occurring once every million years.

b. by polyphase distension, with each episode also modeled as an instantaneous occurrence.

5. Understanding the scenario of polyphase distension requires knowledge of the chronology and kinematics of the distension event, both of which are poorly known. In this study, we chose to use a reconstruction based on seismic and drilling data that was suggested by Boillot et al. (1986). They proposed that the crustal block on which Sites 638,639 , and 641 are located subsided and/or tilted at three distinct times: in the Berriasian $(140 \mathrm{Ma})$, in the latest Valanginian (132 Ma), and in the late Aptian (115 Ma) (Fig. 2 and Table 1).

Coefficients of continental crust thinning $(\beta)$ are significantly higher than the coefficients of surficial extension $(N)$ measured from the horizontal throw of normal faults (Chenet et al., 1982). However, for lack of better constraints, we assumed proportional relations between $\beta$ and $N$. From extension rates estimated from seismic data (Fig. 2) and a value of 3.4 for the coefficient of total thinning, we calculated the distribution of crustal thinning among the various episodes of rifting (Table 1). The resulting subsidence curves (scenarios 1 and 2) are shown in Figure 3. By convention, they represent tectonic subsidence under the water column, without any sediment loading and at a constant sea level.

According to Steckler and Watts (1978), the tectonic subsidence under water $Y i$ at each moment $i$ is given by

$$
Y i=S i \frac{\rho m-\rho S i}{\rho m-\rho w}+H i-\Delta S L i \frac{\rho m}{\rho m-\rho w},
$$

where $S i$ and $\rho S i$ are the thickness and average density, respectively, of the sedimentary column decompacted at the moment $i$; $H i$ is the paleodepth; $S L i$ is sea-level rise in comparison to the present zero level; $\rho m$ is the density of the mantle, in which isostatic compensation (3.2) occurs; and $\rho w$ is the density of seawater.

The equation is solved for the paleodepth $\mathrm{Hi}$ by first calculating $Y i$ using the selected model (Fig. 3) and then subtracting for the effect of sedimentary loading $(S i[\rho m-\rho S i] /[\rho m-\rho w])$ and adding for the effect of the additional water column that results from worldwide eustatism $(\Delta S L i[\rho m /(\rho m-\rho w)])$.

\section{Sedimentation Effects}

Knowing the thickness and weight of the sedimentary layer for each moment $i$ makes calculation of the effects of the sedi- mentary load on the sinking of the seafloor possible, assuming a local isostatic adjustment. However, sediments compact as they are buried under more recently deposited sediments. To determine the original thickness of a sedimentary layer, we need to calculate a progressive "decompaction," assuming that (1) compaction results only from reduction of the initial sediment porosity (i.e., all the solid elements are preserved); (2) compaction is caused only by pressure (i.e., of the weight of the overlying sediments); (3) detrital sediments have the response to compaction as clays, which experience an exponential decrease in porosity with burial (Magara, 1968); and (4) a simple relation exists between sediment density (as measured in the laboratory or by means of diagraphy), petrographic composition, and porosity (Serra, 1979).

We used logging data and density measurements collected aboard the JOIDES Resolution (Boillot, Winterer, et al., 1987) to apply this method of calculating decompaction to the synand post-rift sedimentary sequences drilled at Sites 638, 639, and 641 (Fig. 4). The resulting subsidence curve differs only slightly from that derived by using the compacted sediment thickness measured at the drilling sites. A much greater difference would have resulted if the sedimentary layer overlying the Galicia margin basement were not so thin.

\section{Effects of Eustatic Sea-Level Changes}

Water depth was affected during the Late Cretaceous by a sea-level rise. In order to estimate the increase in the water depth caused by this event, we used a synthetic curve (Fig. 5), constructed by combining Kominz's (1984) curve for the Late Cretaceous to the Holocene and Vail et al.'s ( 1977) curve, calibrated with a maximum of $240 \mathrm{~m}$ for the Tithonian to the Late Cretaceous.

\section{Theoretical Paleobathymetric Curve}

From the model of homogeneous thinning of the lithosphere and the estimated effects on the bathymetry caused by sediment accumulation and eustatic sea-level changes on the Galicia margin, we constructed a theoretical paleobathymetric curve (Fig. 6) from the theoretical subsidence curve (Fig. 3). This curve shows that subsidence occurred in two steps:

1. Initial subsidence (resulting from isostatic reaction to crustal thinning during rifting of the margin) caused deepening of the seafloor to either $2900 \mathrm{~m}$ (scenario 1) or $2750 \mathrm{~m}$ (scenario 2) in a $25-\mathrm{m}$.y. period (140 to $115 \mathrm{Ma}$ ). Thus, it is easy to predict that most of the syn-rift sediments of the Galicia margin were deposited in deep water. 


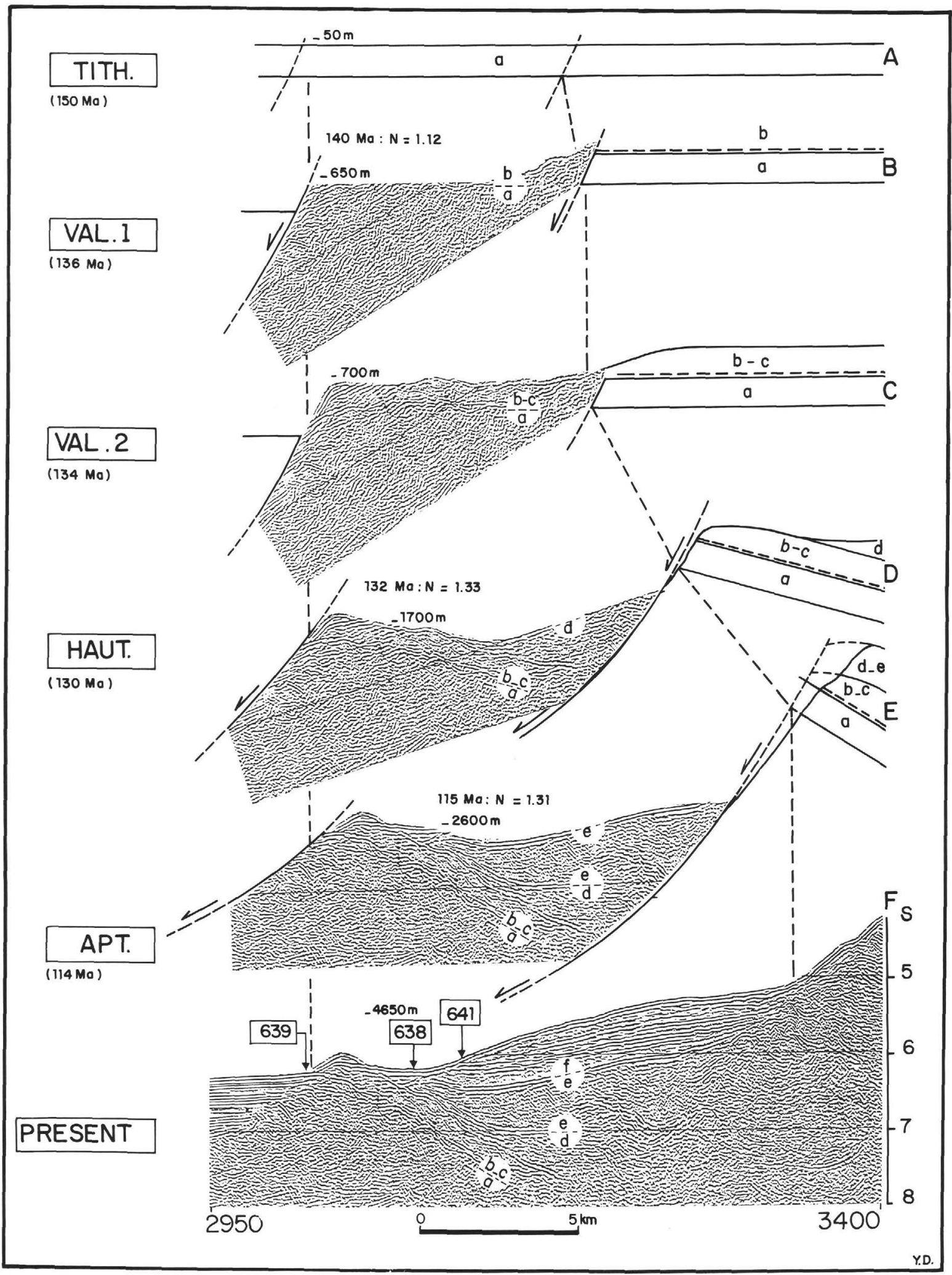

Figure 2. Evolution of the crustal block on which ODP Sites 638,639, and 641 were drilled, reconstructed from drilling data and IFP-CEPM seismic profile GP-101. A = Tithonian; B = early Valanginian; C = latest Valanginian; D = Hauterivian; $\mathrm{E}=$ late Aptian (slightly modified from Boillot et al., 1986). Vertical scale $=\mathrm{s}$ two-way traveltime (TWT). $N=$ coefficient that expresses the surficial distension rates, measured geometrically from the horizontal displacement resulting from normal faults (Table 1). Depths are from the theoretical paleobathymetric curve, scenario 2 (see Fig. 6). 
Table 1. Theoretical lithospheric thinning coefficient $(\beta)$ and surficial extension coefficient $(N)$ of the continental crust from the Tithonian to the late Aptian at ODP Sites 638,639 , and 641 .

\begin{tabular}{lcccc}
\hline \multicolumn{1}{c}{ Time period } & $\begin{array}{c}\text { Age } \\
\text { (Ma) }\end{array}$ & $\begin{array}{c}\text { Time } \\
\text { duration }\end{array}$ & $\beta$ & $\mathrm{N}$ \\
\hline late Aptian & 115 & - & 1.62 & 1.31 \\
latest Valanginian & 132 & - & 1.65 & 1.33 \\
Berriasian & 140 & - & 1.21 & 1.12 \\
Total for the Early Cretaceous & - & 25 & 3.23 & 1.94 \\
Tithonian & 150 & - & 1.05 & n.d. \\
Total since the Tithonian & - & 35 & 3.4 & 1.94 \\
\hline
\end{tabular}

Note: n.d. = none detected.

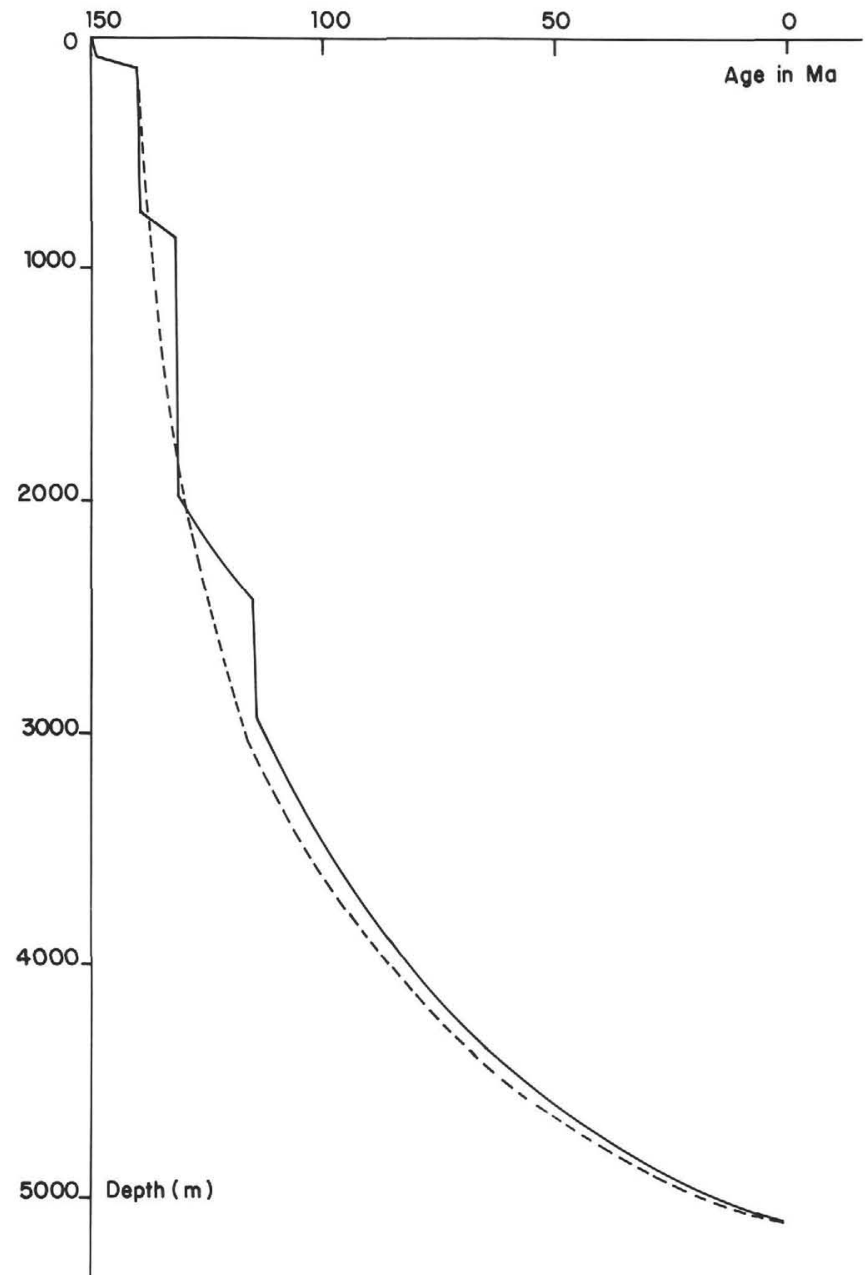

Figure 3. Tectonic subsidence (under water) curves, calculated by using the uniform lithospheric distension model (Royden, 1982). Dashed curve obtained by admitting a distension event in the Tithonian $(150 \mathrm{Ma} ; \beta=$ $1.05)$ and a continuous distension $(\beta=3.21)$ between 140 (Berriasian) and $114 \mathrm{Ma}$ (late Aptian) (total $\beta=3.39$ ). Solid curve obtained by admitting polyphase distension ( $\beta=1.05$ for the Tithonian, 1.21 for the Berriasian, 1.65 for the late Valanginian, and 1.62 for the late Aptian; total $\beta=3.41$ ).

2. Post-rift subsidence, called "thermal" subsidence because it resulted from lithospheric cooling below the henceforth inactive rift, caused a less dramatic deepening of about $2000 \mathrm{~m}$ in $115 \mathrm{~m} . \mathrm{y}$.

Particularly during rifting of the margin, important differences in paleobathymetric evolution appear between scenarios 1 (continuous distension) and 2 (distension distributed in three

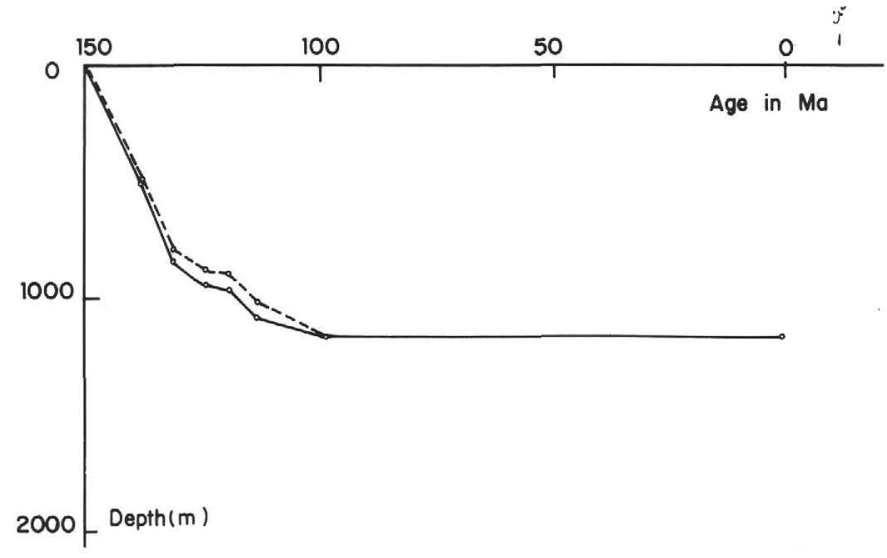

Figure 4. Variation of sediment thickness vs. time, from drilling data of Sites 638, 639, and 641. Dashed line = compacted sediments; solid line $=$ uncompacted sediments.

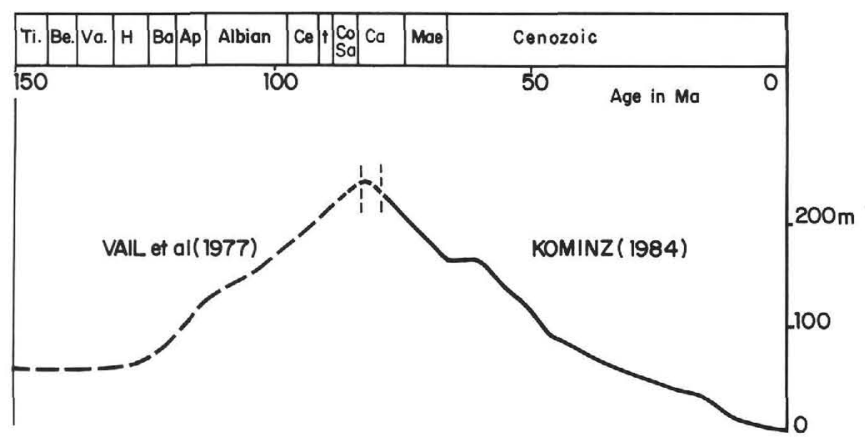

Figure 5. Synthetic curve of eustatic sea-level changes, after Kominz's (1984) and Vail et al.'s (1977) curves (solid and dashed lines, respectively), calibrated with a maximum of $240 \mathrm{~m}$. Ti = Tithonian; $\mathrm{Be}=$ Berriasian; $\mathrm{Va}=$ Valanginian; $\mathrm{H}=$ Hauterivian; $\mathrm{Ba}=$ Barremian; $\mathrm{Apt}$ $=$ Aptian; $\mathrm{Ce}=$ Cenomanian; $\mathrm{T}=$ Turonian; $\mathrm{Co}=$ Coniacian; $\mathrm{Sa}=$ Santonian; $\mathrm{Ca}=$ Campanian; $\mathrm{Mae}=$ Maestrichtian.

phases and separated by periods of inactivity). In the first case, the deepening is faster at the beginning (Valanginian) and then slows (Hauterivian to Aptian). We will discuss these differences and which model best fits the Galicia margin data after the following analysis of paleoenvironmental data and constraints, which were deduced mainly from the faunal content of the sediments.

\section{PALEOBATHYMETRY DEDUCED FROM PALEOENVIRONMENTAL DATA}

Faunal data make it possible to estimate the paleobathymetry of the depositional environment for the following ages.

\section{Pre-Rift Sequence}

\section{Late Tithonian (146 Ma)}

The microfaunal and microfloral assemblages (abundant shallow-water benthic foraminifers, rare calpionellids, oncoids, and a few calcareous algae) found in the calcareous sediments drilled at Site 639 (Shipboard Scientific Party, 1987b) indicate an unzoned platform or "ramp" environment (Moullade, et al., this volume; Loreau and Cros, this volume), devoid of a reefal barrier and under some influence of the open sea. The bioclastic elements show some signs of having been transported, and there are indications, in the upper part of the limestone sequence immediately underlying the dolomite, of a slight deepening in comparison to basal portions of the limestone unit (Moullade, 


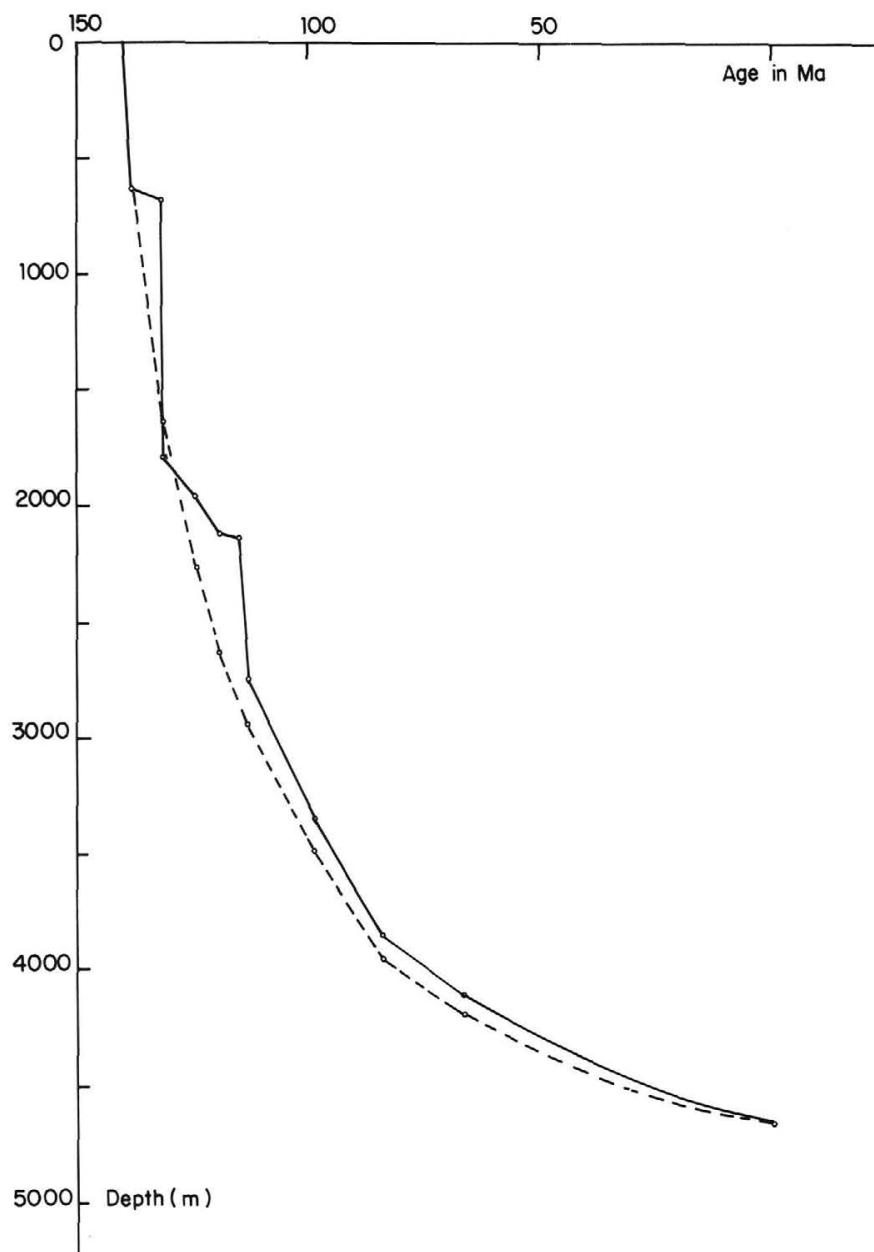

Figure 6. Theoretical water-depth curve at Site 638 , as deduced from the theoretical subsidence curve of Figure 3 after applying correction for eustatic sea-level change (Fig. 5) and sedimentation effects (Fig. 4).

et al., this volume). The average water depth attributed to the depositional environment of these limestones is about $50 \mathrm{~m}$; it certainly did not exceed $100 \mathrm{~m}$.

\section{Latest Jurassic/Earliest Cretaceous (144 Ma)}

The dolomitization phase, associated with erosional processes, that affected the uppermost part of the carbonate section at Site 639 shows characteristics that, according to Loreau and Cros (this volume), suggest emersion. This event is not well dated and occurred between the late Tithonian and early Valanginian (see the following).

\section{Syn-Rift Sequence}

\section{Early Valanginian (136 Ma)}

The Valanginian marls (Calpionellid Zone $\mathrm{E}=$ middle part of the lower Valanginian) that discontinuously overlie the dolomite at Hole 639A contain abundant calpionellids, indicating a significant external influence on the depositional environment. The calpionellids are associated with benthic foraminiferal assemblages, mainly composed of Nodosariids (with mostly lenticulines) and a few agglutinates belonging to the genera Dorothia and, more rarely, Bathysiphon. There are also a few fragments of Aptychii and some ostracodes. Such fauna is characteristic of an outer shelf and/or (preferentially) upper-midslope environment (cf. Guérin, 1981), corresponding to a paleobathymetry of between 200 and $1000 \mathrm{~m}$, but probably closer to 750-1000 $\mathrm{m}$.

\section{Late Valanginian (132 Ma)}

Estimation of the depth of deposition of the middle to late Valanginian sandstones drilled at Holes 638B and $638 \mathrm{C}$ is difficult because these sediments contain only extremely rare faunas; the coarsest beds are entirely barren. Some of the more clayey bands contain a few fragments of Aptychii and very rare foraminifers. These are composed (see Table 2) of a mixture of (1) shallow-water and badly preserved forms (Orbitolinids, Trocholines), (2) outer shelf and epibathyal forms (Nodosariids), and (3) mesobathyal/infrabathyal (Dorothia) and even deeper ( $\mathrm{Ba}$ thysiphon, Ammodiscus) forms. We interpret such a composite fauna as resulting predominantly from transportation to greater depths (at least 2000 to $3000 \mathrm{~m}$, assuming that the deepest agglutinates represent in-situ fauna) of organisms that lived at various, shallower depths together with an enormous amount of detrital terrigenous material that diluted the microfossil component.

\section{Hauterivian/Barremian (130 to $119 \mathrm{Ma}$ )}

The foraminiferal assemblages found in Hauterivian and Barremian sediments recovered at Sites 638 and 641 do not seem to

Table 2. Paleoenvironmental distribution of foraminifers, ODP Hole 638B, in the upper Valanginian/lower Hauterivian. Crosses = neritic forms; open circles = outer shelf-epibathyal forms; solid circles = mesobathyal-infrabathyal forms; triangles $=$ infrabathyal-abyssal forms.

\begin{tabular}{|c|c|c|c|c|c|c|}
\hline 过 & 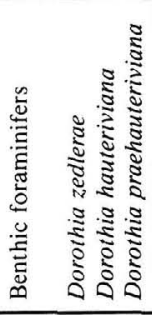 & 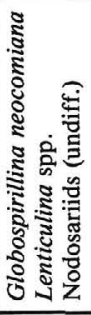 & 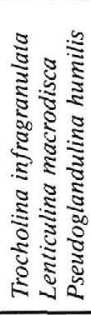 & 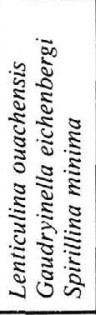 & 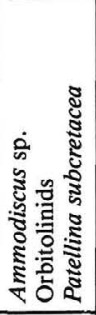 & 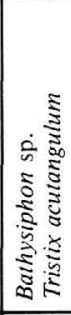 \\
\hline $31 \mathrm{R}$ & $\bullet \bullet$ & 000 & $x$ & & & \\
\hline $32 \mathrm{R}$ & & 0 & 0 & & & \\
\hline $33 R$ & & $\begin{array}{l}00 \\
0\end{array}$ & 0 & 040 & 4 & \\
\hline $34 \mathrm{R}$ & & & & & & \\
\hline $35 \mathrm{R}$ & & & & & & \\
\hline $36 \mathrm{R}$ & & & & & & \\
\hline $37 \mathrm{R}$ & & & & & & \\
\hline $38 \mathrm{R}$ & & 0 & & 0 & $x \times$ & $\Delta$ \\
\hline $39 \mathrm{R}$ & & 00 & & 0 & $X$ & 0 \\
\hline $40 \mathrm{R}$ & & & & & & \\
\hline $41 R$ & & & & & & \\
\hline $42 R$ & & & & & & \\
\hline $43 \mathrm{R}$ & & 00 & & 0 & & \\
\hline $44 \mathrm{R}$ & & & $x$ & 0 & & \\
\hline $45 \mathrm{R}$ & & & & & & \\
\hline
\end{tabular}


represent actual biocoenoses, like those known for the same time in many Tethyan outcrops. Leg 103 assemblages of this age comprise only rare and tiny planktonic forms (Hedbergella) plus a few benthic forms, which are also very small and of very low diversity in comparison with the contemporaneous Vocontian assemblages (cf. Moullade, 1966). It is likely that these assemblages do not represent an in-situ fauna but are elements transported and redeposited by distal turbidites. As a result, it is difficult to accurately estimate the depth of the final environment of deposition, which might have even been below the carbonate compensation depth (CCD), assumed to be at about $2500 \mathrm{~m}$ at that time in the northeast Atlantic, according to Montadert et al. (1979).

\section{Late Aptian (114 Ma)}

The Aptian beds underlying the break-up unconformity (Site 641; Shipboard Scientific Party, 1987c) are composed of turbidites that contain foraminiferal assemblages, most of which are contemporaneous with the deposition process but probably allochthonous. Some scarce neritic forms (e.g., rare Orbitolinids) are found together with more abundant (and sometimes showing signs of dissolution) planktonic specimens, plus deep-water and more diversified benthic forms. If we assume that most of these forms represent in-situ fauna, then we must conclude that they were fossilized at depths close to the CCD $(2200 \mathrm{~m}$ at that time). However, we cannot rule out turbidite transport of all this material, as was the case previously; therefore, the actual paleodepth of Site 641 could be deeper than $2200 \mathrm{~m}$.

\section{Post-Rift Sequence}

With the exception of the abundant calcareous microfaunas, with little or no dissolution effects, that appear to be in place in the Pliocene-Quaternary (CCD was then at about $4500 \mathrm{~m}$ ), the two other sections (Upper Cretaceous and Miocene) of the postrift sequence recovered at the Leg 103 drill sites are characterized by brown or red clays totally devoid of calcareous faunas and definitely deposited below the CCD (close to $4000 \mathrm{~m}$ in Miocene times). The upper Turonian to Maestrichtian red beds of Hole $641 \mathrm{~A}$ contain only agglutinated benthic foraminiferal assemblages belonging to the "Recurvoides Association" (sensu Haig, 1979) that characterize abyssal depths (see Moullade, et al., this volume), close to or probably deeper than $3000-3500 \mathrm{~m}$.

\section{COMPARISON OF THE THEORETICAL MODEL AND PALEOENVIRONMENTAL DATA}

To compare the results of the two different methods, we graphically combined them in a composite figure (Fig. 7). The depth-range estimates for each considered time interval result from the indications given (1) by the faunal content and (2) by the theoretical paleobathymetric curves calculated with the two scenarios of the selected model (Fig. 6).

For the early Valanginian (136 Ma), the microfaunal data indicate a water depth range of 200 to $1000 \mathrm{~m}$, with some indications favoring the deeper values. The theoretical curve shows $1000 \mathrm{~m}$ for scenario 1 (continuous process of subsidence) and $750 \mathrm{~m}$ for scenario 2 (discontinuous subsidence). Thus, there appears to be relatively good agreement between the results obtained by the two different methods, but the paleoenvironmental data do not permit us to constrain the theoretical model and make a choice between the two scenarios.

On the other hand, significant discrepancies arise for the late Valanginian to the Barremian (Table 3). Even when the imprecision of the various methods is taken into account, the paleoenvironmental data appear to suggest a greater amount of subsidence during that time than that predicted by the theoretical model. In the late Valanginian, the paleoenvironmental data in-

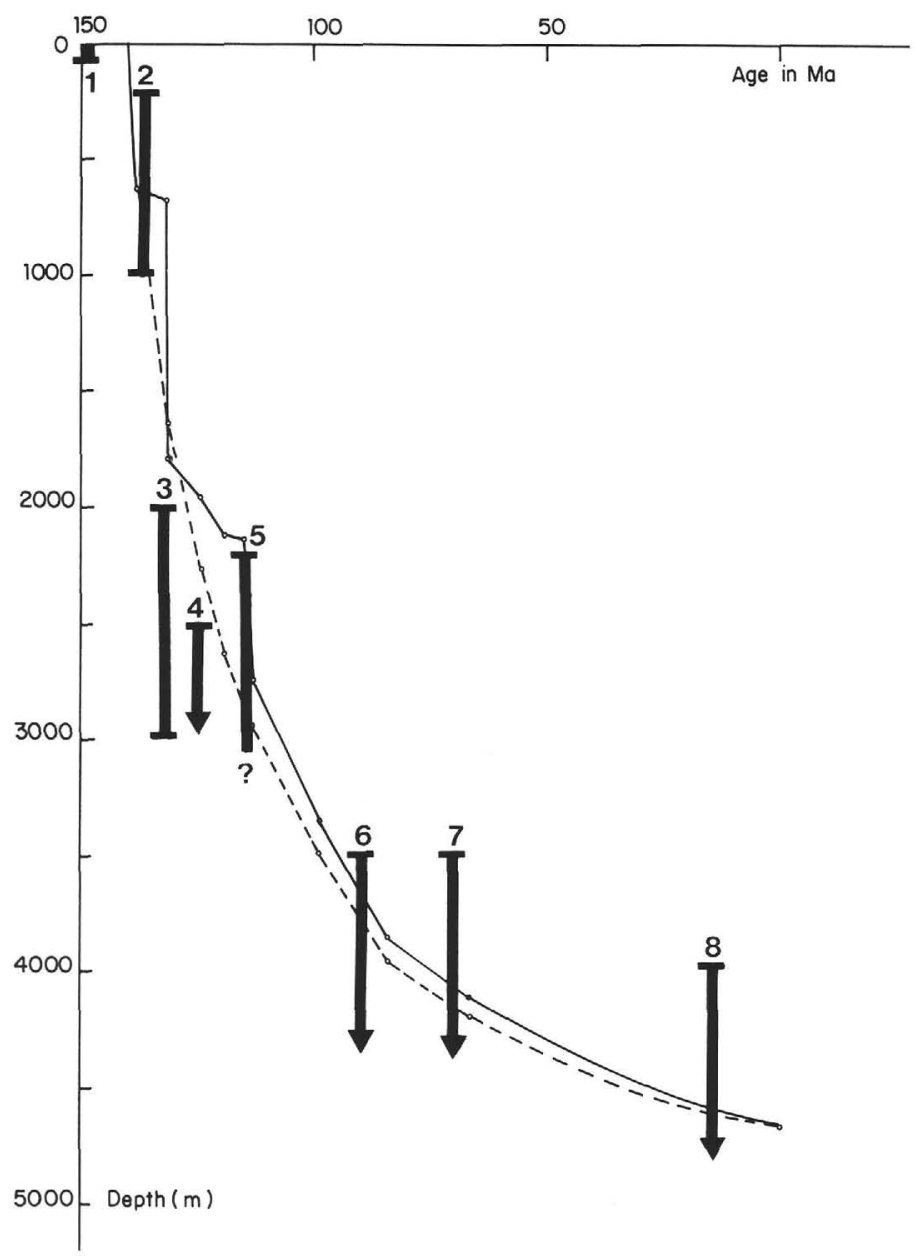

Figure 7. Depth-range estimates, based on paleoenvironmental data (thick lines), superimposed for direct comparison on the theoretical paleobathymetric curves of Figure 6.1 = late Tithonian $(146 \mathrm{Ma}) ; 2=$ early Valanginian (136 Ma); 3 = late Valanginian (132 Ma); 4 = Hauterivian/Barremian boundary (125 Ma); $5=$ late Aptian (114 Ma); $6=\mathrm{Tu}$ ronian $(90 \mathrm{Ma}) ; 7=$ Maestrichtian $(70 \mathrm{Ma}) ; 8=$ Miocene $(15 \mathrm{Ma})$.

Table 3. Comparison of paleodepth estimations based on paleoenvironmental data with those deduced from the paleobathymetric theoretical curve (Valanginian and Hauterivian/Barremian boundary).

\begin{tabular}{cccc}
\hline & \multicolumn{3}{c}{ Paleodepth (m) } \\
\cline { 2 - 4 } Age & $\begin{array}{c}\text { Paleoenvironmental } \\
\text { data }\end{array}$ & Theoretical curve \\
\cline { 2 - 4 } & $>2500$ & 2250 & 1950 \\
\hline $\begin{array}{c}\text { Hauterivian/Barremian } \\
\text { boundary (124 Ma) }\end{array}$ & $2000-3000$ & 1600 & 800 \\
\hline
\end{tabular}

dicate an even faster deepening than that suggested by the theoretical curve corresponding to scenario 1 .

There are no fundamental discrepancies between the results given by the two methods for the late Aptian, Turonian, Maestrichtian, and Miocene. The theoretical curves permit us to limit the extent of the bracketing depth intervals given by the microfaunal data.

\section{DISCUSSION}

In summary, the preceding detailed comparison reveals a relatively good agreement between the paleoenvironmental data and the theoretical subsidence curves. However, it remains nec- 
essary to explain the divergence that appears for the late Valanginian and persists, though attenuated, through the Hauterivian-Barremian. There are several possibilities to explain these discrepancies:

1. The theoretical model that we used does not take heat loss by lateral conduction into account. Such a loss is difficult to calculate but is a likely cause of additional subsidence, estimated at $200-400 \mathrm{~m}$ from the data of Watremez (1980) and Alvarez (1984). This could partly explain the discrepancy, in the Neocomian, between the paleoenvironmental data and the systematically underestimated predictions of the theoretical model.

2. It is also possible to question our selection of McKenzie's (1978) model, which supposes that lithospheric stretching was homogeneous. The Leg 103 scientific party, on the basis of other data, used a model that implies heterogeneous lithospheric stretching, as derived from Wernicke (1985) (Boillot et al., 1986, 1987). Unfortunately, it is very difficult to predict subsidence accurately with such a model (see Coward, 1986). These difficulties are further increased by the lack of precise data for the Galicia margin on the geometry and kinematics of the detachment fault postulated by Wernicke (1985). We were thus constrained in using the homogeneous stretching model, which is well documented but possibly not entirely suitable for the area. Features of the initial (syn-rift) subsidence differ between the two models. In the homogeneous stretching model (Fig. 8A), the isostatic reaction to the crustal thinning is partly compensated by the effects of significant thermal flow. Inversely, according to the heterogeneous stretching model, crustal thinning occurs in an area where the lithosphere is moderately thinned (Fig. 8B) and, therefore, the heat flow remains low. Only in the last phase of rifting, when the thinning zone of the lithosphere moves closer to the rift axis, does heat flow increase. In other words, the heterogeneous lithospheric stretching model implies a faster and greater initial subsidence than the homogeneous stretching model used in this paper.

This theoretical model is limited, especially by the relative imprecision of the paleobathymetric reconstructions based on micropaleontologic data. Nevertheless, the rapid subsidence of the margin in the Valanginian, as deduced from the faunal content of the sediments, is generally more consistent with Wernicke's (1985) model than with that of McKenzie (1978). Although our study does not choose among the proposed models, it does not contradict the heterogeneous lithospheric stretching hypothesis.

\section{ACKNOWLEDGMENTS}

Michel Moullade and Gilbert Boillot thank the Ocean Drilling program for inviting them to participate on Leg 103 aboard the JOIDES Resolution. The authors are indebted to Alain Mauffret and Denis Mougenot for valuable discussions. Audrey W. Meyer and an anonymous reviewer kindly helped us in improving our manuscript. This work was supported by French C.N.R.S. Grants "ATP Géologie-Géophysique des Océans" no. 1243 and ASP "Soutien ODP-France" no. 1433.

Contribution no. 449 of the "Groupe d'Etude de la Marge Continentale" (Université de Paris VI and CNRS UA 718).

\section{REFERENCES}

Alvarez, F., 1984. Etude de l'évolution thermique des bassins sédimentaires formés par extension. Conséquences thermo-mécaniques du rifting. Application au Graben Viking (Mer du Nord) [Thesis]. Univ. Paris VI.

Boillot, G., Recq, M., Winterer, E. L., Meyer, A. W.. Applegate, J., Baltuck, M., Bergen, J. A., Comas, M. C., Davies, T. A., Dunham, K., Evans, C. A., Girardeau, J., Goldberg, D. G., Haggerty, J., Jansa, L. F., Johnson, J. A., Kasahara, J., Loreau, J. P., Luna Sierra, E., Moullade, M., Ogg, J., Sarti, M., Thurow, J., and Williamson, M. A., 1986. Amincissement de la croûte continentale et dénu- dation tectonique du manteau supérieur: à la recherche d'un modèle-l'exemple de la marge occidentale de la Galice (Espagne). Bull. Cent. Rech. Explor. Prod. Elf Aquitaine, 10:95-104.

1987. Tectonic denudation of the upper mantle along passive margins: a model based on drilling results (ODP Leg 103, western Galicia margin, Spain). Tectonophysics, 132:335-342.

Chenet, P., Montadert, L., Gairaud, H., and Roberts, D., 1982. Extension ratio measurements on the Galicia, Portugal, and northern Biscay continental margins: implications for evolutionary models of passive continental margins. In Watkins, J. S., and Drake, C. L. (Eds.), Studies in Continental Margin Geology: Mem. Am. Assoc. Pet. Geol., 34:703-715.

Coward, M. P., 1986. Heterogeneous stretching, simple shear and basin development. Earth Planet. Sci. Lett., 80:325-336.

Guérin, S., 1981. Utilisation des foraminifères planctoniques et benthiques dans l'étude des paléo-environnements océaniques au Crétacé moyen: application au matériel des forages D.S.D.P. de l'Atlantique Nord et Sud. Comparaison avec la Tèthys [Thesis]. Univ. de Nice.

Haig, D. W., 1979. Global distribution patterns for mid-Cretaceous foraminiferids. J. Foraminiferal Res., 9:29-40.

Kent, D. V., and Gradstein, F. M., 1985. A Cretaceous and Jurassic geochronology. Geol. Soc. Am. Bull., 96:1419-1427.

Kominz, M. A., 1984. Oceanic ridge volumes and sea-level change. An error analysis. In Schlee, J. (Ed.), Interregional Unconformities and Hydrocarbon Accumulation: Mem. Am. Assoc. Pet. Geol., 36:109127.

Le Pichon, X., and Sibuet, J.-C., 1981. Passive margins: a model of formation. J. Geophys. Res., 86:3708-3720.

Magara, K., 1968. Compaction and migration of fluids in Miocene mudstone, Nagaoka plain, Japan. AAPG Bull., 52:2466-2501.

McKenzie, D. P., 1978. Some remarks on the development of sedimentary basins. Earth Planet. Sci. Lett., 40:25-32.

Montadert, L., de Charpal, O., Roberts, D., Guennoc. P., and Sibuet, J.-C., 1979. Northeast Atlantic passive continental margins: rifting and subsidence processes. In Talwani, M., Hay, W., and Ryan, W.B.F. (Eds.), Deep Drilling Results in the Atlantic Ocean: Continental Margins and Paleoenvironment: Am. Geophys. Union, Maurice Ewing Ser., 3:154-186.

Moullade, M., 1966. Etude stratigraphique et micropaléontologique du Crétacé inférieur de la "fosse vocontienne." Doc. Lab. Geol. Fac. Sci. Lyon, 15.

Royden, L. H., 1982. The evolution of the intra-Carpathian basins, and their relationship to the Carpathian mountain system [Ph.D. thesis]. Massachusetts Institute of Technology.

Serra, O., 1979. Diagraphies Différées. Bases de L'Interprétation. 1: Acquisition des Données Diagraphiques: Mem. Cent. Rech. Explor. Prod. Elf Aquitaine, 1.

Shipboard Scientific Party, 1987a. Introduction, objectives, and principal results: Ocean Drilling Program Leg 103, west Galicia margin. In Boillot, G., Winterer, E. L., et al., Proc. ODP, Init. Repts., 103: College Station, TX (Ocean Drilling Program), 3-17.

, 1987b. Site 639. In Boillot, G., Winterer, E. L., et al., Proc. $O D P$, Init. Repts., 103: College Station, TX (Ocean Drilling Program), 409-532.

1987c. Site 641. In Boillot, G., Winterer, E. L., et al., Proc. ODP, Init. Repts., 103: College Station, TX (Ocean Drilling Program), 571-649.

Steckler, M. S., and Watts, A. B., 1978. Subsidence of the Atlantic-type continental margin off New York. Earth Planet. Sci. Lett., 41:1-13.

Vail, P. R., Mitchum, R. M., and Thompson, S., 1977. Seismic stratigraphy and global changes of sea-level. In Payton, C. E. (Ed.), Seismic Stratigraphy: Applications to Hydrocarbon Exploration: Mem. Am. Assoc. Pet. Geol., 26:49-212.

Watremez, P., 1980. Flux de chaleur sur le massif armoricain et sur la marge continentale: essai de modélisation de l'évolution thermique de la marge continentale [Thesis]. Univ. de Bretagne Occidentale.

Wernicke, B., 1985. Uniform-sense normal simple shear of the continental lithosphere. Can. J. Earth Sci., 22:108-125.

Date of initial receipt: 23 February 1987

Date of acceptance: 19 January 1988

Ms 103B-129 


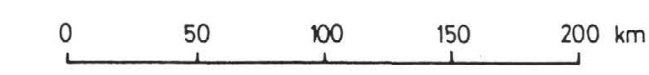

A
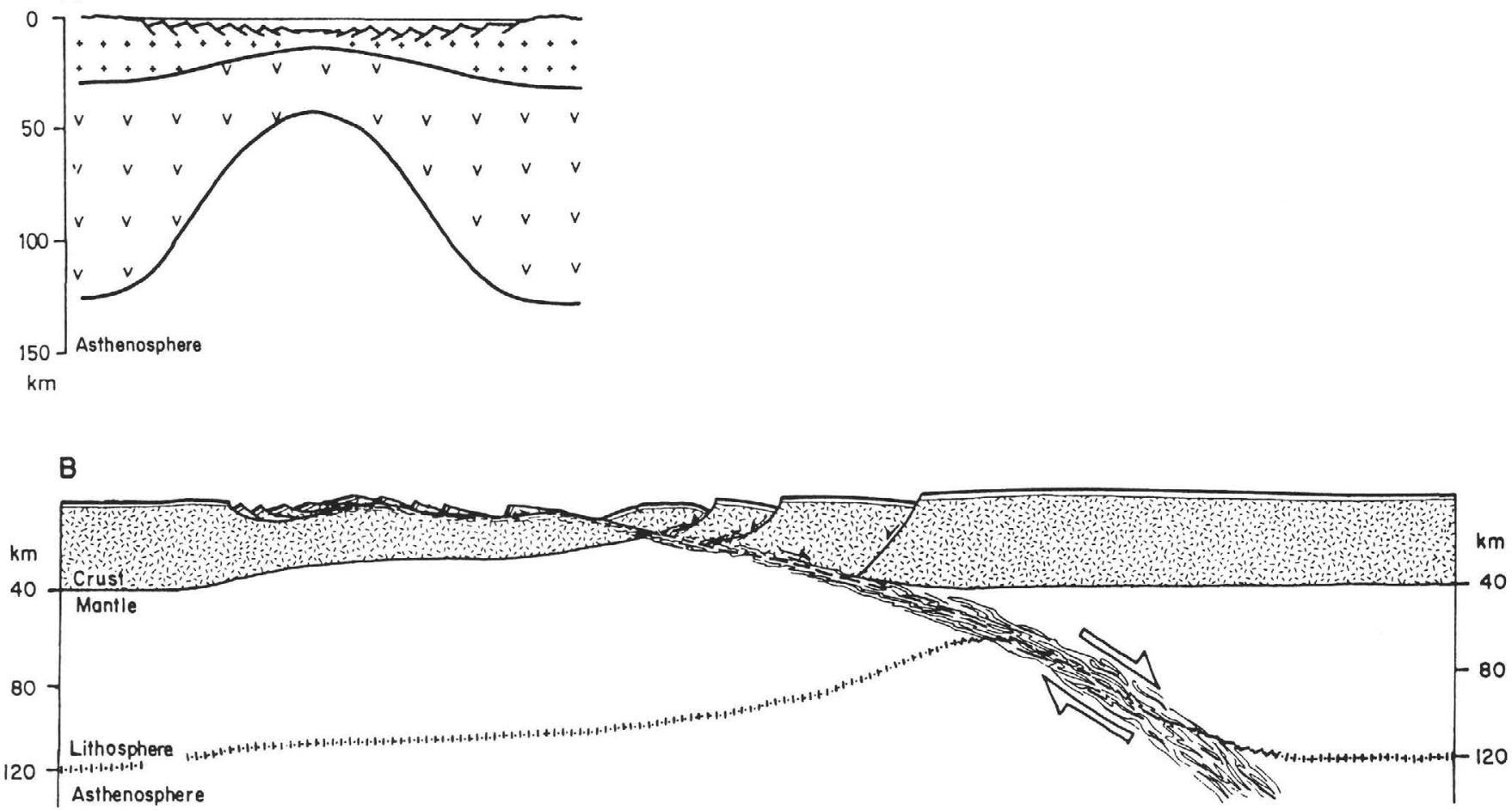

Figure 8. Models of lithospheric stretching. A. Homogeneous stretching model used in this paper (McKenzie, 1978; Le Pichon and Sibuet, 1981). B. Heterogeneous stretching model, as proposed by Wernicke (1985). 